\title{
La cuestión nacional en Cuba hasta la primera guerra de Independencia.
}

\author{
Roberto Cassá ${ }^{1}$
}

\section{Introducción}

Mientis ientras que a partir de 1808 en la generalidad de las colonias españolas se iniciaron procesos que desembocarían en la proclamación de la independencia, en Cuba la dominación metropolitana pudo sostenerse. El mantenimiento de los cubanos bajo el colonialismo español se prolong6 a lo largo del siglo XIX, constituyendo, junto con Puerto Rico, un caso especial en America Latina.

El propósito del presente artículo será rastrear las posibles causas que determinaron la prolongación de la dominación española y considerar los procesos económicos y las luchas sociales que se desarrollaron en este contexto. Interesa, en ese sentido, determinar los marcos económicos y macrohistoricos que establecieron pautas diferenciadas entre el proceso cubano y el del resto de países latinoamericanos. Con este propósito, es necesario examinar las posiciones de los distintos grupos sociales ante la cuestion de la autodeterminación, lo que permitirá establecer algunas comparaciones con lo sucedido en el continente.

Es difícil generalizar acerca de los determinantes que llevaron a los procesos latinoamericanos de independencia. Probablemente, la elaboración de una teoría que abarcase todos los casos nacionales requeriría tomar en consideración variables muy diversas. ${ }^{2}$ Las motivaciones de las fuerzas sociales que intervinieron en los procesos estuvieron mediadas por circunstancias que se establecían en distintos planos de la realidad social, de acuerdo con contextos particulares de formación nacional y de evolución política coyuntural. Esto remite a los condicionamientos que provenían de la división de la población en grupos sociales (indígenas, negros, mestizos y mulatos, criollos y peninsulares, etc.), sobre los cuales se ordenaban las clases sociales. A su vez, la forma en que se relacionaban esos grupos sociales posibilitaba determinados planos de avance en la formación de un conglomerado nacional. El hecho nacional, en su etapa inicial, que $\mathrm{E}$. Torres Rivas califica de nacionalidad, ${ }^{3}$ estuvo muy relacionado al grado de evolución económica, por cuanto éste potenciaba la aparición de factores sociales susceptibles de generar un proyecto

1 El autor agradece los útiles comentarios al presente texto hechos por las profesoras Ana Carolina Ibarra y Dení Trejo.

2 De hecho, tales teorías existen: incluso se han popularizado, dando lugar a ciertas nociones de sentido común, por lo que obviamente contienen generalizaciones difícilmente aceptables hoy. Es lo que explica las tendencias a replantear los problemas que muestran algunos especialistas en historia del continente, como Tulio Halperin Donghi, en Historia contemporánea de la América Latina, Madrid, 1977. Pierre Chaunu, por su parte, se aboca a una crítica sistemática de los presupuestos tradicionales, aunque no of rece una explicación alternativa. Cfr. Pierre Chaunu, et al, La independencia de América Latina Buenos Aires, 1969.

3 Cfr. Edelberto Torres R., "La nación: problemas políticos y teóricos", en N. Lechner (ed.), Estado y politica en América Latina, México, 1983. 
político alternativo al de la metrópoli, mediante esquemas de poder ya esbozados en la conformación de los grupos dominantes locales.

Otro aspecto que debe ser considerado estriba en que el surgimiento de esos factores sociales requería un plano cultural vital en la praxis de las clases, como lo pone de relieve Edward Thompson. ${ }^{4}$ Pero, más allá de que una clase o fracción solidificara su acción apoyada en una cosmovisión cultural, una ruptura tan trascendente como la independencia suponía que al menos ciertos aspectos de dicha cosmovision fueran extendiéndose, durante el proceso de lucha, a otros sectores de la población.

Por último, habría que apuntar a lo coyuntural, por cuanto las sucesivas resoluciones que iban arrojando las luchas sociales y nacionales imponían giros específicos y actitudes, tanto de corta como de larga duración, en las fuerzas sociales envueltas en ellas. Esto parte del supuesto de que la independencia no fue un hecho predeterminado, sino que su virtualidad resultaba de un proceso que iba incorporando resoluciones acumulativas.

De tal manera, la explicación en conjunto de la formación de las naciones y de los estados de América Latina se presenta como una problemática bastante compleja. Supone abordar en forma multilateral los factores determinantes que operaron sobre los procesos de independencia. Por lo mismo, se debe partir de una relación muy precisa entre factores locales e incidencias generales, lo que permite desechar explicaciones generales que no toman en cuenta lo local. En este sentido, vale señalar un tipo de conexión entre las diversas sociedades, que podríamos llamar efectos en cadena; esto es, ciertas circunstancias podían estar ausentes en un contexto determinado, pero hacerse presentes por su acción en otro contexto. Esto permitiría comprender la formación de tendencias continentales que trascienden los accidentes particulares.

En torno a los anteriores presupuestos abstractos, hay que abordar algunos de los problemas presentes en las explicaciones genéricas de la independencia. El primero, el concerniente al supuesto de que el esquema colonial estaba agotado - dado el estado de somnolencia de España, a pesar de las reformas borbónicas - e impedía el desarrollo de las fuerzas productivas; de ese supuesto se ha inferido que los conflictos entre criollos y metrópoli conducían necesariamente a la idea de la independencia. Otro supuesto muy manejado se refiere a los precedentes inmediatos, los cuales habrían preparado los condicionamientos psicologicos para la ruptura con España. Por último, la quiebra del estado español - tras la deposición de la dinastía borbónica por Bonapartese invoca como catalizadora, en el plano sociopolítico, de una crisis preexistente: el vacío de poder facilitó e impuso al mismo tiempo la irrupción política de las aristocracias criollas.

Parece estar fuera de duda que, efectivamente, el estado español, estructuralmente considerado, estaba cada vez más inhabilitado para adecuarse a los avances que se llevaban a cabo en el mercado mundial a consecuencia de la revolución industrial inglesa. El hecho mismo de las reformas borbónicas, resultante de la asunción deliberada de los retos que presentaba la expansion mercantil británica, desembocó en un rotundo fracaso, a la larga contraproducente para la estabilidad de la economía española. ${ }^{5}$ De la misma manera, no cabe duda de que la 
apertura de una etapa de grandes revoluciones burguesas imponía límites políticos a las posibilidades de reproducción del colonialismo hispánico. Por ello, la explicación económica que trata de dar cuenta de las causas profundas del proceso no puede disociarse de la social y de la política; de otra manera, no se explicaría que la independencia se produjera en el umbral de una redefinición del colonialismo, por más que ésta fuera parcial y tardía. Incluso, habría que hacer intervenir el hecho de que esencialmente los núcleos criollos no representaban una alternativa avanzada del statu quo, sino más bien era conservadora, 1o que complica el análisis general. Este hecho no fue ajeno a que el medio siglo que siguió a la independencia se caracterizara por la depresión económica y por el fortalecimiento de formas socioeconómicas arcaicas.

Tratando de sintetizar esta discusion, se podría proponer la existencia de factores de agotamiento en el orden economico, aunque no fuesen absolutos. De la misma manera, se podría también, tentativamente, señalar niveles de maduración política de los grupos sociales, lo que a largo plazo podría contribuir a precipitar las contradicciones en un nivel antagónico. En ese sentido, las reformas borbónicas tuvieron efectos disímiles; si por una parte permitieron la obtención de mayores rendimientos a los grupos dominantes criollos —al quedar liberados obstáculos monopólicos seculares- también generaron, en sentido contrario, malestares profundos por cuanto las inspiraba el posibilitar una profundización de la explotación colonial. ${ }^{6}$ Por último, los procesos de formación nacional tendían a preparar condiciones favorables a la ruptura con España, pero aún no habían madurado. Se mantenían profundas segmentaciones en la población, las cuales estorbaban la consolidación de los conglomerados nacionales, y todavía el interés de los grupos sociales no se manifestaba a través de la confrontación con el poder metropolitano en tanto que sistema, sino por medio de aspectos sectoriales que implicaban su existencia.

En relación a los puntos del párrafo anterior, no parece que, en víspera de la abdicación de Carlos IV, los grupos dominantes criollos estuviesen en disposicion de orientarse hacia la ruptura con España, lo cual plantea en ellos un cierto desfase en torno a los procesos de constitución del colectivo nacional. ${ }^{7}$. Las clases populares, por otra parte, no habían orientado sus luchas en torno a la contradicción con España; en tal sentido se aprecia que los precedentes, generalmente considerados como la rebelión de Tupac Amaru, no tuvieron una conexión con los hechos posteriores a 1808; más bien, tendieron a retraer ciertas posiciones radicales entre los criollos, como efectivamente sucedió en Cuba ante la sublevación de esclavos en la vecina Saint Domingue.

De tal manera, se hace problemático el establecimiento de líneas in-

Stein, La herencia colonial de América Latina, México, 1986, p. 98 y ss. Para ulteriores detalles, James Lockhart y Stuart Schwartz, Early Latin America: A history of Colonial Spanish America and Brazil, Cambridge, 1985, p. 352-368. Para el caso mexicano, el más relevante de su aplicación, En rique Florescano e Isabel Gil Sánchez, "La época de las reformas borbónicas y el crecimiento económico, 1750-1808", en Bernardo García Martínez, et al., Historia general de México, tomo I, p. 471-590.

6 Véase David Brading, Mineros y comerciantes en el México borbónico (1763-1810), México, 1985.

7 Es lo que, por ejemplo, sostiene Halperín para el caso argentino, donde los criollos con mucha rapidez alcanzaron una excepcional compactación en el designio de desligarse de España. Cfr. Tulio Halperín Donghi, Revolución y guerra, México, 1979. 
terpretativas sobre el papel de las masas populares. Dos líneas divergentes han tocado el punto: las que ponen el énfasis en que las guerras de independencia fueron hechos protagonizados por las masas populares y las que dirigen la atención a la acción de las aristocracias criollas. Quizás ambas sean demasiado rígidas, puesto que no toman en cuenta las diferencias que provienen de los casos nacionales y de sus etapas. ${ }^{8} \mathrm{Se}$ podrían tomar dos de los ejemplos más relevantes para ilustrar las situaciones cambiantes. En México, la acción de Morelos e Hidalgo está sustentada en la rebelión agraria popular, pero en Venezuela son los mantuanos esclavistas los que se adelantan a un vacío de poder para garantizar sus interes y prevenir la insurgencia popular. ${ }^{9}$ En México, tras la derrota de la masa popular, son los criollos dirigidos por Iturbide quienes proclaman la independencia; en Venezuela, ante la destrucción del ejército mantuano y la incapacidad de España para adecuarse a las demandas de la masa explotada, la independencia toma un contenido finalmente popular y liberal, aunque no traspasa el universo de los sectores dominantes.

De manera que, ciertamente, las masas populares se constituyeron en factor de importancia a lo largo de los procesos. Pero esto se llevo a cabo de manera desigual; al no excluir, en lo fundamental, la hegemonía criolla, no se desembocó en ninguna situación histórica de proyecto popular, con la excepción muy problemática de Haití. En sentido inverso, en alguna ocasión habría también que ver en la acción de las masas populares contra la independencia, quizás en parte una manera más efectiva de captación de sus intereses profundos, enfrentados a la élite criolla tanto o más que a la propia metrópoli. Las resoluciones ulteriores explicitan esas frecuentes orientaciones, ya que las reformas liberales se dirigían contra las formulas de defensa de las condiciones de vida que habían conformado las masas oprimidas. Por lo anterior, podría concluirse que las luchas populares se superpusieron y se integraron paralelamente, de forma desigual y a menudo contradictoria, en los procesos independentistas sin que llegaran a constituir la nota dominante.

\section{Peculiaridades del caso cubano}

Al margen de las determinaciones sociales, la prolongación del dominio español sobre Cuba se facilito, en gran medida, por la condición insular. Como es sabido, los procesos de independencia en América del Sur no dejaron de estar potenciados por un factor en cadena explicable por las posibilidades de comunicación entre los territorios. Así, la independencia en el subcontinente se vio garantizada por las huestes de Bolívar o de San Martín, que actuaban como ejércitos internacionales y quebraban los puntos fuertes en que se apoyaban los españoles.

La condición de insularidad evitó que el efecto en cadena se extendiera a Cuba. De tal manera, se fortalecieron los condicionamientos

8 A pesar de lo sugerente, y de la tentativa de escapar a los términos tradicionales del debate, la siguiente propuesta de Pierre Vilar mantiene planos de generalidad: "En efecto, la cohesión entre masas y minorías a menudo no es sino una consecuencia de la represión. ¿No es acaso la verificación de un hecho general que el sentido de grupo es ofensivo entre las minorías en el poder (o que quieren estarlo)? En la masa es defensivo y es menos razonado". Pierre Vilar, "La participación de las clases populares en los movimientos de independencia de América Latina", en Pierre Chaunu et al., op. cit., . 56-57. 9 Para una visión de conjunto, que integra ambos casos, véase a John Lynch, Las revoluciones hispanoamericanas, Barcelona, 1977. 
sociales que estorbaban que se detonara un cuestionamiento al poder español. Esta dificultad operó en un sentido de resignación entre los núcleos independentistas del continente. Es cierto que en 1825 , con motivo de la celebración del Congreso de Panamá, entre los gobiernos de México y la Gran Colombia se ponderó la organización de una expedición para la liberación de Cuba. La diplomacia de los Estados Unidos mostró abierta oposición a la proyectada expedición, con lo que terminó por frustrarse. Es probable que lo que estuviese detrás de la posición norteamericana fuese el proposito de anexar la isla para transformarla en un estado de la unión. Es evidente que si Cuba obtenía la independencia, la incipiente formulación de la doctrina del Destino Manifiesto tendría mayores dificultades para realizarse. Para los políticos que habían acogido las proposiciones de Jefferson, parecía más viable que España, por su extrema debilidad, se viera forzada en breve a aceptar la venta de la isla. Pero, aunque tradicionalmente se ha achacado la no realización de la expedición a esa oposición norteamericana, documentos que han ido apareciendo indican que, desde cierto momento, Bolívar en verdad no estuvo dispuesto a llevar a cabo el proyecto. Lo vio muy riesgoso y lo pondero simplemente como un medio de presión hacia España, en lo cual estaba implícito que se sacrificaba la independencia de Cuba. ${ }^{10}$

Ahora bien, en el caso de que la expedición se hubiese efectivamente realizado, nada permite considerar que se hubiera saldado con la victoria. Desde que se abrieron las guerras de independencia, España procedió a concentrar un enorme ejército en la isla, convertida, junto a Puerto Rico, en una línea de retaguardia de sus ejércitos en el continente, $y$ luego en verdadera base contrarrevolucionaria, donde se concentraron los refugiados realistas. Pero más importante que el hecho militar de que constituía el bastión colonialista, era la actitud de los sectores criollos, entre los cuales se había impuesto la unificación política en torno a la solidaridad con España.

En lo que se refiere a esta diferenciación del proceso cubano, fueron varios los determinantes históricos que intervinieron, tanto en lo económico como en lo político. Entre todas las colonias españolas de América, Cuba era la única que desde fines del siglo XVIII tenía un sistema esclavista intensivo. Es cierto que en otras colonias de la zona del Caribe, principalmente en Venezuela, existía una esclavitud bastante desarrollada; pero, a diferencia de Cuba, en Venezuela la hacienda esclavista no cuajo del todo, ${ }^{11}$ hecho extensible con mucha más razón a colonias como Puerto Rico y Santo Domingo. ${ }^{12}$

La economía cubana había entrado en una fase de intenso crecimiento a partir de la ocupación británica de La Habana en $1762 .{ }^{13}$ A consecuencia de las medidas introducidas por los británicos en su breve estadía, el gobierno español debio otorgar significativas concesiones a la clase de hacendados esclavistas en el sentido de introducir prerrogativas específicas del régimen de libre comercio. Y, efectivamente, el auge

10 Cfr. Hugh Thomas, Cuba: la lucha por la libertad, Barcelona, 1973, tomo I, p. 146-148.

11 Germán Carrera Damas, Una nación llamada Venezuela, Caracas, 1980, p. 43.

12 Respecto a Santo Domingo, véase Rubén Silié, Economía, esclavitud y población. Santo Domingo, 1976; para Puerto Rico, Francisco Scarano, Sugar and Slavery in Puerto Rico, Madison, 1984.

13 Cfr. Franklin W. Knight, "Origins of Wealth and the Sugar Revolution in Cuba, 17501850", Hispanic American Historical Review, vol. 57, núm. 2 (mayo de 1977), p. 231-253. 
económico particular que registró la isla desde la última década del siglo XVII estuvo asociado a la conexión directa con el mercado mundial y, dentro de éste, muy especialmente con el mercado norteamericano.

Esta política coincidió con tendencias cada vez más definidas en los círculos gobernantes ilustrados españoles. Es posible que el caso cubano fuera único en cuanto a efectivas concesiones librecambistas, pero, por otra parte, actuó como catalizador de la presión para conseguir disposiciones generales, válidas para todas las colonias, que fueron emanando en los años siguientes a la ocupación de La Habana: en 1765 se eliminó el sistema de flotas entre España y América, disposición que tenía implícita la apertura de numerosos puertos a ambos lados del océano y la eliminación del monopolio que ejercían los comerciantes de Cádiz. En 1778 se dictó una cédula que reglamentaba la libertad de comercio desde esos puertos con casi todos los puertos importantes de las colonias. ${ }^{14}$

No obstante esas concesiones del Estado español, los conflictos de parte de los hacendados no lograban encontrar un cauce de resolución. Más bien parece que tendieron a intensificarse a escala continental, puesto que las presiones externas se hacían progresivamente mayores a causa de las transformaciones que estaban experimentando las economías del occidente europeo y de las variaciones políticas que siguieron a la Revolución francesa.

En Cuba, contrariamente, las presiones que ejercieron los hacendados posibilitaron la aludida generalización del librecambio, lo que permitió a los círculos dominantes locales mantener la solidaridad con la dominación metropolitana. Claro que esta actitud política no puede explicarse sólo a partir de la referida determinación: tampoco porque la economía cubana se encontrara en una etapa de auge. Otras colonias, en las cuales se incubaron los procesos independentistas, también se encontraban en una etapa de ascenso económico antes de 1810 , y ese contexto más bien coadyuvó a disparar nuevas contradiccciones.

Lo que sucedió en Cuba tuvo una doble vertiente económica y política. Si bien era normal el auge economico a instancia de las reformas borbónicas, en Cuba tendió a tener mayor cuantía que en el conjunto de colonias, incluyéndose las más favorecidas. Pero más importante era el hecho de que este auge se llevaba a cabo por medio de la generalización de la esclavitud intensiva. De tal manera, al darse el ascenso económico en marcos productivos esclavistas, las clases propietarias se unificaron en torno al temor de una sublevación negra. Este estado de ánimo estaba motivado por los acontecimientos que se produjeron en la vecina colonia francesa de Saint Domingue desde 1789. La cuestión haitiana tuvo especiales significaciones por cuanto el auge azucarero cubano $-y$ los esclavistas cubanos estuvieron en todo momento conscientes de ello- se correspondió con la ruina de la vecina colonia francesa, hasta ese momento la más rica del mundo y, en especial, la que dominaba el mercado de varios géneros tropicales, como el azúcar, el café, el añil y el cacao. ${ }^{15}$

El compromiso de los criollos de Cuba con el rumbo esclavista comportaba definiciones políticas decisivas. Por una parte, el sometimiento de contingentes cada vez mayores de trabajadores a la esclavitud de plan- 
tación impedía que surgieran reflejos nacionales que se tradujesen en el esbozo de un proyecto de todo el colectivo. Por el contrario, la autopercepción de los criollos esclavistas suponía la exclusión del resto de la población. Tal exclusión trascendía los esclavos por cuanto los criollos requerían afianzar un poder omnímodo sustentado en su proclama de superioridad racial y moral sobre la mayoría no blanca de la población. $\mathrm{Si}$ bien hacían aparición atisbos de conciencia nacional entre una parte de los criollos, la misma tenía una connotación restrictiva sobre el propio conglomerado privilegiado. Implicaba por ello, a lo sumo, una intelección nacional anti-popular, barnizada con un acendrado racismo. Al legitimarse la dominación social con el argumento racial, los criollos tenían que reconocer su subordinación con respecto a los intereses metropolitanos y, en cierta manera, a los de la población de peninsulares, que a fin de cuentas representaba la máxima expresión de excelencia moral y política. A los criollos, por lo demás, no les interesaba destacar la idea de autodeterminación, pues primaba en ellos la búsqueda del beneficio al margen del régimen político. ${ }^{16}$

En ese contexto, se facilitó que, no obstante el mantenimiento y a veces agudización de las contradicciones de los criollos respecto a la dominación metropolitana, se tuviera que ratificar la fidelidad hacia ésta. Los criollos requerían de un aparato legitimador ante ellos mismos y el resto de la población, un enmarcamiento dentro de un poder extenso que les confiriese seguridad en la medida en que no generaban un reflejo nacional, $y$, por último, una garantía coercitiva ante el peligro de los esclavos.

Otros factores convergieron para que no surgiera un movimiento sólido de cuestionamiento a la dominación española. Al hacerse creciente la masa de esclavos, ${ }^{17}$ se aplazaba la compactación de la población alrededor de una percepción de comunidad. El particularismo social tenía en los esclavos un corolario inevitable de su condición social, máxime en las duras condiciones de auge de la plantación exportadora. Los esclavos ni siquiera podían aproximarse a la intelección grupal similar a la de los criollos. Se encontraban distantes entre sí, y no podían percibir, como masa, ninguna idea de comunidad global, con mucho menos razón si incorporaba a otros sectores sociales. Carecían de proyecto político alguno, y su único reflejo social consistía en alcanzar individualmente la libertad personal. El excepcional régimen represivo que se implantó desde fines del siglo XVIII acentuó en Cuba las dificultades de aparición de reflejos sociales colectivos en la masa esclava.

Desde el ángulo socio-cultural, en el estrato opuesto al de los esclavos, el de los peninsulares, la idea de comunidad nacional cubana tam-

16 El presbítero Félix Varela, uno de los más preclaros intelectuales cubanos del siglo XIX, no obstante su vínculo orgánico con el interés de los criollos, al asumir en su exilio una posición distante, reconoció que en Cuba "no hay opinión política, no hay otra opinión que la mercantil. En los muelles y almacenes se resuelven todas las cuestiones de Estado.". Varela, "Consideraciones sobre el estado actual de la isla de Cuba" (1824), reproducido por Hortensia Pichardo, op. cit., p. 277-280.

17 De acuerdo con las estimaciones de otro prestigioso intelectual criollo, José Antonio Saco, hasta 1595 sólo se introdujeron 12 mil esclavos; desde esa fecha hasta 1740 , unos 40 mil; de 1740 a 1789 , otros 46 mil; esto es, hasta el estallido de la revolución haitiana entraron casi 100 mil esclavos africanos. En cambio, entre 1790 y 1821 de manera legal ingresaron a la isla $240 \mathrm{mil}$, a los que el investigador suma otros 60 mil de contrabando, sumando pues $300 \mathrm{mil}$. En tres décadas entraron tres veces más esclavos que en las 28 décadas anteriores de dominio español. Véase Saco, "Análisis", en Hortensia Pichardo, op. cit., p. 293-309. 
biên estaba excluida; simplemente, se consideraban españoles, y Cuba era una extensión de la península, donde ellos estaban llamados a gozar de privilegios en razón de su condición étnica.

La idea de lo nacional sólo surgía, en consecuencia, en los albores del siglo XIX, primordialmente entre los débiles sectores medios urbanos. Éstos, sin émbargo, se encontraban fragmentados entre los grupos de blancos y de gente de color. Los primeros, por su parte, no dejaban de mostrar temores a verse desbordados por la rebelión de los esclavos, de forma que a lo sumo tendieron a colocarse bajo la hegemonía de los pequeños sectores de criollos que se ubicaron tras posiciones autonomistas o independentistas. Por ello, aunque en algunos movimientos por la independencia surgiera cierto liderazgo criollo, en realidad éste expresba efectivamente la práctica de los sectores medios, pues hasta la segunda mitad del siglo XIX, los esclavistas como clase nunca dejaron de ser opuestos a toda forma de idea de autodeterminación.

\section{La política económica de España y los intereses de los esclavistas cubanos}

La prevención a jugar con el fuego de la independencia que mostraron las elites criollas de la isla no significaba la inexistencia de contradicciones con la métropoli. En realidad, los conflictos se acrecentaron a medida que se desarrollo el orden esclavista, por cuanto la clase hacendada requería reformas sustanciales que a menudo contravenían los términos en que se desenvolvía la dominación española. Al respecto vale hacer algunas aclaraciones. Por una parte, aunque España había otorgado especiales concesiones librecambistas a Cuba, en ningún momento se resignó, hasta 1817-18, a una generalización definitiva del sistema. Por esta razón se reiteraron prohibiciones al comercio directo con los Estados Unidos, aunque normalmente las mismas no se cumplieron por la autonomía de que gozaban los capitanes generales a causa de las guerras de fines del siglo XVIII. Es también lo que aconteció con Someruelos, uno de los gobernadores más inclinados a favorecer los intereses de los criollos, desde el momento en que Bonaparte destronó a la dinstía borbónica. Hay que entender que España se aferraba a un mínimo de control monopólico sobre sus colonias, frente a adversarios que se le habían adelantado considerablemente en el desarrollo capitalista. En sentido contrario, los criollos cubanos encontraron, después de 1763 , mecanismos eficaces para presionar a las autoridades a que tolerasen o propiciasen prácticas librecambistas. En ese sentido, tendió a emerger una alianza de intereses entre las facciones burocraticas de origen peninsular y los esclavistas criollos en fase rápida de expansión.

Cuando se hizo evidente la situación catastrófica en que se encontraba el imperio, hubo que abandonar las tentativas de mantener controles monopólicos tradicionales, lo que determinó disposiciones completamente librecambistas en 1818.18 El propósito era obvio: una tentativa

18 La apertura comercial total hacia otras naciones, acordada mediante decreto de 1818 , se acompañó por otras no menos importantes, dentro del expreso propósito de recomponer la alianza entre la monarquía y los esclavistas criollos. En particular, tuvo mucha relevancia el decreto de 1817 por medio del cual se eliminó el estanco del tabaco y se dejaban libres las actividades de su siembra, manufactura y exportación. No menos destacado fue el decreto de 1819 que reconocía la propiedad plena sobre las tierras que hubiesen sido entregadas en calidad de mercedes, entonces el grueso de las tierras de la isla; la no composición de las mercedes estorbaba la expansión de los hacendados al inzposibilitar la mercantilización đe los bienes rústicos y limitar los montos de inversiones que se arriesgaban. Véase Hortensia Pichardo, op. cit., p. 260-266. 
de rehacer un pacto con las clases dominantes criollas de todo el continente. Sin embargo, ya era tarde y esta variación de políticas sólo tendría efectos de largo plazo en Cuba y Puerto Rico. Ahora bien, un nuevo nivel de conflictos aparecio con el sacrificio del monopolio colonial, dado por las funciones extraordinarias que ejerció Cuba en el estado español durante todo el siglo XIX. España tuvo que permitir que su única colonia de importancia desde 1822-24 se hiciese un apendice factual de la economía norteamericana, a cambio de poderle extraer ingentes beneficios financieros. El monarca Fernando VII trascendio sus posiciones absolutistas y se fijo la meta de sellar una alianza solida con los hacendados cubanos, premiando su fidelidad a la monarquía con sucesivas concesiones económicas. A cambio de estas concesiones, los hacendados, a su vez, tendrían que consentir en la entrega de fracciones importantes de los excedentes de sus empresas para fines del sostenimiento de la monarquía. Desde el ángulo económico, el pacto era muy incómodo para los criollos esclavistas, pero se vio universalmente como inevitable durante varias décadas.

Los objetivos derivados del pacto se realizaban a través de varios procedimientos. Primero, por medio de una relación comercial con Estados Unidos caracterizada por un fuerte superávit. En segundo lugar, con la importancia de las exportaciones metropolitanas a la isla, las cuales se sostenían artificialmente a cuenta del superávit con Estados Unidos. Tercero, mediante la aplicación de elevadas tarifas aduaneras: desde fines del siglo XVII ya había un arancel de $20 \%$, el cual se elevó bruscamente, con la permisión del librecambio, a un $36 \%$.

Este esquema permitía al Estado español obtener importantes sumas a partir de las ganancias comerciales y los impuestos. El total de recaudaciones previo a la ocupación inglesa era de unos 160 mil pesos; para 1860 llegó a 20 millones y en vísperas de la Guerra de los Diez Años, esto es en 1868, a 27 millones. Sumas muy elevadas del presupuesto local se destinaban directamente a la península, agregándose a los valores que se trasladaban por medio de la ganancia comercial o el traslado de capitales. De todas formas, los recursos que se consumian en la isla, concentrados en guerra, marina y hacienda, 19 aseguraban el status a la muy numerosa burocracia civil y militar proveniente de la península y formaban parte crucial de los dispositivos militares globales del Estado español. Se explica que, de hecho, el segundo personaje en jerarquía dentro de la administración de la monarquía fuese el gobernador de Cuba.

Desde mediados de siglo, cerca de la mitad del presupuesto del gobierno español provenía, directa o indirectamente, de recursos extraídos de la isla. Esta importancia desmesurada se ampliaba por la formación de un mercado protegido para las manufacturas generadas por la naciente burguesía industrial española. Al parecer, tal relación tuvo especial incidencia en la metropoli, los industriales catalanes, como lo puso de relieve Cepero Bonilla, ${ }^{20}$ constituyeron el grupo de presión más intransigente en contra de cualquier posibilidad de independencia de Cuba e incluso de abolición de la esclavitud.

19 En el presupuesto de gastos de 1862 , el $26 \%$ se destinó a guerra, el $12 \%$ a marina, el $33 \%$ a hacienda; el envío directo de fondos a la península representó el $16 \%$ de lo presupuestado. Los recursos dedicados a la inversión directa interna fueron insignificantes (menos del $4 \%$ ), otro motivo de queja de parte de los hacendados. Cfr. Hortensia Pichardo, op. cit., p. 364.

20. Cfr. Raúl Cepero Bonilla, Azzicar y abolición, Barcelona, 1977. 
Naturalmente, esa poderosa incidencia de la isla sobre España provocaba múltiples contradicciones con los grupos dominantes locales, específicamente con los esclavistas. Estos captaban con perfecta claridad que los sistemas tributarios y arancelarios estaban concebidos para el traslado de una porción considerable de la riqueza social en beneficio de las elites metropolitanas. Ese convencimiento se compensaba con la idea de que la dominación española era inevitable hasta en tanto se encontrara una solución que garantizara la no ocurrencia de una revolución de los esclavos.

\section{La irrupción política de los hacendados: los primeros reformistas}

Alrededor de la búsqueda de soluciones intermedias, y sublimando las contradicciones con el imperio español a través de una integración ilustrada, emergió una corriente política de gran importancia: los reformistas. Más que en cualquiera otra forma, dicho movimiento constituyó la expresión más poderosa de los hacendados esclavistas. El movimiento surgió en torno a la fundación en 1872 de la Sociedad Económica de Amigos del País que, a semejanza de las que se habían constituido en España, tuvo funciones de institución de fomento, centro cultural y educativo, club social, núcleo de presión, etc. En todas esas disímiles actividades sobresalio como ideologo de la Sociedad y, por ende, de los intereses de los criollos esclavistas, el ilustrado plantador, bien versado en cuestiones económicas, Francisco de Arango y Parreño.

El planteo de ese colectivo estuvo dirigido a crear las condiciones para que Cuba se tornase una colonia rica, basada en el uso de la esclavitud intensiva, al igual que lo habían sido Jamaica y Saint Domingue. Esto requería reformas de parte de las autoridades, tendentes a facilitar la inserción de la isla en el mercado mundial; esto es, el programa reformista planteaba el tránsito de una forma de colonialismo a otra que concediera espacios a las aspiraciones que entonces emergían entre los propietarios. 21

En gran medida, la reivindicación de los reformistas estuvo dirigida a defender al sector de hacendados contra la subordinación a que estaban sometidos por la elite comercial. Mientras la gran mayoría de los hacendados eran criollos de la vieja aristocracia colonial, los comerciantes, en su casi totalidad, eran de origen extranjero, sobre todo de la península. De tal manera, el conflicto de intereses económicos de ambas clases se trasladaba a un ámbito de oposición nacional. Los hacendados identificaban sus intereses a los del territorio insular y tenían conciencia de ser distintos al concepto genérico de españoles; sin embargo no se puede decir que entre ellos hubiese surgido, hasta la segunda mitad del siglo XIX, un concepto sobre el hecho nacional. En cambio, para los comerciantes peninsulares Cuba era una parte de España, identificación que no estorbaba una autopercepción de superioridad frente al nativo de la isla. Por razones obvias, de esta cosmovisión participaba el cuerpo burocrático, en su inmensa mayoría compuesto por peninsulares, aunque con una disposición un tanto más armonizadora.

Esa mediación del cuerpo burocrático no era óbice para que, en lo esencial, constituyera el eje articulador de la subordinación de todos los 
estamentos nacionales cubanos, incluyéndose los hacendados esclavistas. Particularmente, la superioridad económica de los comerciantes peninsulares sobre los hacendados criollos era un corolario inevitable de la dominación colonial en su conjunto. $Y$, en esa medida, la existencia de conflictos entre ambas clases dominantes resultaba ser consustancial con la subordinación a la metropoli. En el plano económico, la hegemonía de la clase mercantil reproducía las relaciones desventajosas a que estaba reducida la isla por España. Incluso, los comerciantes, en su calidad de peninsulares, canalizaban hacia la metropoli parte considerable de sus excedentes. Ello explica que el orden colonial les confiriera privilegios corporativos que ratificaban ventajas previas, resultantes de su articulación con el mercado mundial. De tal contexto se explica que todo el complejo productivo estuviese dominado por la clase mercantil metropolitana, lo que resultaba en abierto perjuicio de la clase esclavista.

La posición de desventaja del productor esclavista respecto al comerciante al parecer fue mucho mayor que en otras sociedades de plantación. De manera que en este punto se mantuvo un punto crítico que reproducía la divergencia entre intereses dominantes. Esa desventaja puede explicarse por el hecho de que el nivel inicial con el que partieron los plantadores en su expansión como clase era exiguo, dada la mediocridad económica de la isla antes de 1762. Esta exigüidad contrastó con requerimientos compulsivos de recursos debido al alza rápida del precio de los esclavos (sobre todo, tras 1807, cuando Inglaterra unilateralmente prohibió la trata negrera) y a la necesidad de introducir maquinarias caras en el contexto de la revolución industrial inglesa como único medio de sostener la competitividad en el mercado mundial. La rapidez con que creció la producción de azúcar y de café determinaba que las plantaciones debieran recurrir de forma creciente al crédito. De tal manera, los esclavistas podían amasar grandes fortunas, pero por fuerza seguían dependiendo de los créditos de los comerciantes. ${ }^{22}$

En el plano económico, la superioridad se lograba por el mayor rendimiento del capital invertido en la esfera de la circulación en relación al invertido en la productiva. El proteccionismo mercantil metropolitano no era ajeno, naturalmente, a este sesgo, aunque chocara con la eficiencia del sistema en su conjunto. Los esquemas tributarios y arancelarios reforzaban tendencias propias de un orden colonial, puesto que en definitiva eran los esclavistas los que tenían que sacrificar fuertes porciones de los excedentes. De tal manera, aun durante todo el proceso de auge, los hacendados capitalizaron a un ritmo sustancialmente menor que el que lograban los comerciantes.

Originalmente los esclavistas pudieron capitalizar contando con el crédito directo de comerciantes ingleses, por cuanto el problema crucial para la reproducción ampliada consistía en el aprovisionamiento de esclavos. En la medida en que se introdujo el librecambio, se eliminaron los asientos de la trata negrera, hecho que, a su vez, facilitó que la ignominiosa actividad pasara a ser controlada por los comerciantes establecidos en la propia isla, no pocos de ellos con experiencias previas en la trata.

$\mathrm{El}$ acrecentamiento de la producción en el sistema esclavista determinaba, por fuerza, una entrada masiva de nuevos esclavos. De hecho, hasta mediados del siglo XIX el sistema se sostuvo sobre la base de una 
tendencia creciente, en el largo plazo, hacia la introducción de mano de obra esclava. Así, de 1815 a 1820, por ejemplo, se sabe que entraron unos 100 mil esclavos, y de la última fecha a 1860 otros 400 mil. ${ }^{23}$ Para esta última fecha, ya el precio de un esclavo de trabajo agrícola estaba cercano a los mil pesos, en tanto que a inicios de siglo era inferior a los doscientos pesos. El precio del azúcar, en cambio, experimentó una baja después de 1815; luego, se mantuvo estable hasta 1850 para, por último, entrar en una curva descendente en las tres décadas siguientes. Ese alto costo de la inversión resultaba cada vez más impracticable para los esclavistas. Se encontraban atrapados entre los requerimientos crecientes de créditos a tasas usurarias y la tendencia al descenso de los precios.

En parte, el abuso que cometían los comerciantes se amparaba en una cédula real de 1529 otorgada a los esclavistas de Santo Domingo y puesta en práctica en Cuba hacia 1595; mediante esa cédula se declaraban inembargables los ingenios azucareros, de manera que otorgarles créditos en apariencia comportaba grandes riesgos.

En sus reclamos a los comerciantes y a la metrópoli por las desventajas a que eran sometidos los hacendados, los reformistas optaron por una política de negociación. Lograron ser escuchados por las autoridades por dos razones: la primera, la coincidencia de intereses que mostraba la metrópoli respecto al desarrollo económico de la isla; en segundo lugar, la disposición expresa del grupo a no embarcarse en actitudes antiespañolas, motivada por el temor a que en tal contexto intervinieran los esclavos y se reiterase el paradigma haitiano. Estos dos principios explican por qué varios gobernadores, como Luis de las Casas, expresamente protegieron a esa expresión política de los hacendados.

\section{Los primeros movimientos por la independencia}

Los esclavistas tenían sus razones para temer a la insurgencia de los esclavos y, en general, de las personas de color. Ello obedecía a que la proporción de tales sectores en el total de la población no cesaba de incrementarse; de haber sido minoritarios en los años 60 del siglo XVIII, para 1790 negros y mulatos ya constituían la mayoría; poco tiempo después, los esclavos suponían aproximadamente un $41 \%$ de la población, proporción que se mantendría hasta alrededor de $1850 .{ }^{24}$ Para liberarse de esos temores, los reformistas impulsaron las ideas de la colonización blanca, iniciándose un programa de fomento a la inmigración de peninsulares, inspirado por Arango, desde 1817.

Los temores de los esclavistas también partían de las posibles influencias que pudieran llegar desde la vecina Saint Domingue-Haití. $Y$, en efecto, en 1797 se descubrió la primera gran conspiración de esclavos, dirigida por Nicolás Morales, un negro liberto, calificado por

23 Cfr. Hugh Thomas, op. cit., caps. 9, 10 y 11.

24 El siguiente cuadro ilustra la evolución porcentual de los grupos de color:

$\begin{array}{ccccc}\text { Años } & \text { Blancos } & \text { Esclavos } & \begin{array}{c}\text { Libres } \\ \text { de color }\end{array} & \begin{array}{c}\text { Total } \\ \text { de color }\end{array} \\ 1775 & 56 \% & 26 \% & 18 \% & 44 \% \\ 1791 & 49 & 31 & 20 & 51 \\ 1817 & 43 & 37 & 20 & 57 \\ 1827 & 44 & 41 & 15 & 56\end{array}$

Fuente: José Antonio Saco, art. cit., p. 301. 
algunos como el Toussaint cubano. Aparentemente el movimiento no se dirigía a la proclamación de la independencia, sino a la abolición de la esclavitud, actitud entonces muy normal en movimientos de esclavos. Sin embargo, el hecho contenía una carga subversiva intolerable para las autoridades. Así, cuando fue develado dio lugar a una persecución sistemática de las tentativas libertarias; ejemplo de ello fue la creación de los cuerpos de rancheadores, profesionales en la persecución de esclavos cimarrones.

Cuando en 1808 se inició en España la insurrección contra los franceses, en varios puntos de América se crearon Juntas de Gobierno. En Cuba, el hecho se reiteró por iniciativa del propio gobernador, quien contó con el respaldo de los reformistas y la resistencia de los peninsulares y de los organos que defendían sus intereses de manera directa. Los reformistas intentaron capitalizar la situación para hacer valer de manera definitiva sus reivindicaciones, como la de plena libertad de comercio.

No obstante la relativa hegemonía reformista, en ese contexto se presento el primer movimiento popular abierto, en torno a la constitución de la Junta de La Habana, que en muchas de sus consecuencias propendía hacia la independencia y el logro de reivindicaciones sociales avanzadas. Tales posiciones partían de la emergencia, todavía limitada, de sectores medios que identificaban sus intereses con la independencia y un programa de corte liberal. Ello explica que, a pesar de la hegemonía de los hacendados en los medios deliberativos y del control político completo de las autoridades, la Junta tuviera que discutir una invitación recibida desde Caracas para tomar parte en la separación de la metrópoli. El llamamiento de los venezolanos provocó bastante entusiasmo en las masas populares urbanas y no dejo de sensibilizar a algunas porciones minoritarias de los hacendados, pero finalmente fue rechazado.

Sin embargo, la apertura política contribuyó a facilitar la gestación del primer movimiento por la completa independencia de la isla, en 1809. Estuvo acaudillado por Román de la Luz, un masón de clase media. Los hacendados criollos se negaron a secundar la conspiración, y ésta fue descubierta. Todavía la clase media no disponía de fuerza para actuar políticamente aislada de los criollos, en tanto que los esclavos y libertos seguían operando con otros parámetros sociales. Esta subordinación de los sectores medios al liderazgo de pequeños núcleos criollos se manifesto en las propias limitaciones de la conspiración en cuestion. Uno de sus inspiradores, el abogado masón Joaquín Infante, después de haber escapado a Venezuela, publicó un proyecto de constitución en 1812. Significativamente, el proyecto estipula que sólo los americanos blancos podrán participar en la elección de los diputados del estado imaginario. Por otra parte, el artículo 84 prescribe que "en el orden político se observará la distinción de clases que queda establecida, llevando los blancos la prelación en cuya posesión se hallan por origen y anterioridad de establecimiento, siguiendo los pardos, y últimamente los morenos". El artículo 89 mantiene la institución de la esclavitud aunque "baxo principios conciliadores de equidad, justicia, y retribución". 25

La diferencia de intereses y de posiciones políticas entre sectores medios y masas oprimidas se evidenció en la falta de apoyo de estas últimas al movimiento independentista que lidereo De la Luz y de las primeras

25 "Proyecto de Constitución para la Isla de Cuba", en Hortensia Pichardo, op. cit., p. 253-260. 
a la conspiración que tres años después organizara José Antonio Aponte. La conspiración de Aponte, que tuvo ramificaciones entre esclavos de toda la isla, sobre todo de las plantaciones de la zona occidental, tenía por objetivo repetir la experiencia haitiana, no siendo casualidad que el dirigente negro fuese un hechicero de deidades africanas. Al ser develado el complot, estallaron insurreciones en varias plantaciones, generando profundos temores en los criollos y solidificando su identificación con la metrópoli mientras no surgiera otra alternativa viable.

La crisis de la autoridad central del estado español llevó a que los hacendados criollos asumieran lineamientos ofensivos, en parte amparándose en la agitación de los sectores medios. Particularmente, tal tipo de movimientos cobró fuerza tras el establecimiento de moldes institucionales en la monarquía. De manera que, con el vacío relativo de poder del absolutismo, tanto entre 1808-1812 como en 1821-1823, se agravaron las tensiones entre criollos y peninsulares. Los criollos buscaron conquistar posiciones aprovechando que contaban con la mayoría de los electores para delegados a las Cortes. En resolución del Ayuntamiento de La Habana del 4 de septiembre de 1810, se solicita la generalización del libre comercio, al tiempo que los hacendados firmantes se encargan de hacer valer sus criterios, en una peculiar forma de externar dudas al respecto, para la elección del delegado. ${ }^{26}$

Los hacendados intentaron capitalizar la representación legislativa de la isla para, por una parte, cuestionar la hegemonía de los mercaderes y, por la otra, acentuar la tiranía sobre los esclavos. Es significativa la virulencia con que el Ayuntamiento de La Habana respondio al propósito de los diputados españoles Guridi y Argüelles para atemperar a la solicitud inglesa de la prohibición de la trata negrera. ${ }^{27}$ Estos propósitos despóticos ya estaban expuestos en la larga relación redactada por Arango en 1792, titulada "Discurso sobre la agricultura de La Habana y medio de fomentarla",28 pieza maestra del programa reformista de los hacendados. Plásticamente, Arango señala lo siguiente:

Pero la insurreción de los negros de Guarico ha agrandado el horizonte de mis ideas.

Al ruido de este funesto suceso, he despertado y he visto que toda mi obra se sostenía en el aire; que nada había trabajado para darle subsistencia, que el sosiego y reposo de todos mis compatriotras, el goce de las felicidades que iban a conseguir estaba pendiente de un hilo: de la subordinacion y paciencia de un enjambre de hombres bárbaros.

No es hoy cuando más me espanta esta desagradable advertencia... mis grandes recelos son para lo sucesivo, para el tiempo en que crezca la fortuna de la Islay tenga dentro de su recinto quinientos mil o seiscientos mil africanos. Desde ahora hablo para entonces, y quiero que nuestras precauciones comiencen desde el momento.

Las actitudes radicales de los sectores medios cobraron cuerpo en la década de 1820, tras la reinstauración del absolutismo, cuando captaron

26 Cfr. Hortensia Pichardo, op. cit., p. 203-209. Es bien significativo que dicha resolución fuese firmada por los líderes del partido criollo, entre los cuales se encontraban, además del diputado electo Andrés de Jáuregui, Francisco de Arango y Parreño, el conde de O'Reilly (futuro cabecilla de los movimientos de los criollos), el marqués de Cárdenas, el conde de Casa-Montalvo, el marqués de Casas-Peñalver y muchos otros conspicuos integrantes de la aristocracia esclavista.

27 El documento fue redactado por Arango, y presentado el 20 de julio de 1811. Cfr. Hortensia Pichardo, op. cit. p. 219-252.

28 En Hortensia Pichardo, op. cit. p. 190. 
que el gobierno español no podría satisfacer sus expectativas. Se abrió la etapa más activa en pos de la independencia antes de 1868: se dio un gran movimiento popular urbano que resultó del alineamiento de la mayoría de la población con el llamado partido criollo como uno de los grupos que se disputaban la hegemonía tras la restauración del régimen constitucional en la metrópoli. Los hacendados, sin embargo, no pudieron capitalizar esa coyuntura, por cuanto, como se ha visto habían sido recompensados por Fernando VII en premio a su fidelidad. Curiosamente, por ese motivo, cuando se declararon las luchas entre comerciantes y hacendados, los primeros se pronunciaron por el régimen constitucional, provocando motines en toda la isla. Mientras tanto, sectores importantes del partido criollo, dirigido por O'Reilly, tuvieron que adoptar posiciones radicales para oponerse a las pretensiones de los peninsulares. Uno de sus representantes electos a Cortes, el presbítero Félix Varela, exigio, por primera vez en Cuba, la abolición de la esclavitud, e hizo alegatos en pro de un régimen autonómico.

Cuando en 1823 retornó al absolutismo los criollos no pudieron mantener sus posiciones. En la coyuntura de los años 20 la expresión abierta de intereses dominantes contrapuestos tuvo resultados muy distintos a los de 1808 en adelante. En el contexto tradicionalista que siguió a la entrada de los hijos de San Luis a la península, el discurso autonómico que conspicuos criollos habían expuesto resulto muy sospechoso. De manera que Fernando VII varió de actitud, optando por la implantación de un régimen de excepción en la isla. En 1825, en efecto, dispuso la promulgación de las denominadas "facultades omnímodas", reiteradas en 1834. Por medio de las mismas, el capitán general recibía la potestad de deportar cualquier persona y detener el procedimiento que le pareciera conveniente, no importa de cual otra autoridad proviniese. En ese entorno legal, los criollos pasaron a ser subordinados plenamente por el Estado español, el cual se orientó a nulificarlos políticamente. El pacto no se rompía porque se siguieron observando las concesiones librecambistas, pero a la larga el grueso de los criollos pasó a considerar que el mantenimiento de la autoridad española constituía un obstáculo a sus intereses. El anexionismo hacia Estados Unidos se hizo así la expresión política dominante. De todas maneras, en ningún momento llego a implicar una ruptura beligerante del acatamiento a la autoridad española. Ahora bien, todavía en los años 20 , tras la disolución del partido criollo, algunos núcleos minoritarios volvieron a orientarse a la práctica conspirativa en colusión con los sectores medios radicalizados.

La agitación de los sectores medios culminó con una conspiración que, al igual que la de Aponte, tenía ramificaciones en todo el territorio. Se trató de una organización que tomó por nombre "Soles y Rayos de Bolívar", al parecer con mucha influencia masónica. Se conformó, como viene de señalarse, al fracasar el partido criollo de $O^{\prime}$ Reilly, tras la restauración del absolutismo, pero supuso un significativo cambio por cuanto se propuso la consecución plena de la independencia. Su máximo dirigente, José Francisco Lemus, había tomado parte en la agitación pública de años antes y mantenía estrechas relaciones con agentes del gobierno colombiano. En la sociedad secreta participaron blancos, sobre todo de clase media - junto a otros vinculados a la clase hacendada, como el gran poeta José María Heredia- así como pardos y negros. De manera que se estaba ya armando, aún de manera harto incipiente, una síntesis nueva en materia de cohesión nacional. La sociedad secreta fue descubierta en 1828 y faltarían 40 años para que esa síntesis nacional pu- 
diera manifestarse en la lucha armada. De todas maneras, durante los años 20 la agitación independentista no cejo, como lo muestra el hecho de que, tras ser apresado Lemus, se organizara otra sociedad secreta, llamada "Aguila Negra", descubierta dos años después sólo de manera parcial, aunque quedó claro que se trató también de un amplio movimiento. ${ }^{29}$

Con el trasfondo de represión que siguió a la promulgación de las "facultades omnímodas" convergieron otros fenómenos, como el abandono de las proclamas en apoyo activo a la independencia de Cuba por los gobiernos de Colombia y México, el giro de la política norteamericana hacia la solidaridad con España, la recuperación posterior de los reformistas y la subrepticia presencia, detrás de ella, del anexionismo, tornado en el reflejo político decisivo entre los hacendados esclavistas. De tal forma, cesó durante décadas la agitación de los sectores medios. Gran parte de los mismos incluso tuvo que enfilar sus sentimientos anti-españoles a través del anexionismo.

\section{El anexionismo de los hacendados}

La delicada situación en que se encontraban los esclavistas se agudizó cuando, por requerimientos competitivos en el mercado mundial, entre 1830 y 1840 se inició en Cuba una activa mecanización del procesamiento industrial del azúcar. Los elementos principales de esta transformación tecnológica estuvieron vinculados a la introducción de la máquina de vapor al proceso productivo y, luego, al transporte en ferrocarril. Cuba fue uno de los primeros países del mundo que construyo un sistema ferroviario, mucho antes que los restantes países de América Latina, e incluso que España. Los requerimientos de capital para la maquinización se veían entorpecidos por los que resultaban de la adquisición de los esclavos. Esta contradicción generó un verdadero impasse entre los hacendados, quienes, en su casi totalidad, terminaron en la bancarrota entre 1860 y $1880 .{ }^{30}$ El control del sector azucarero, cada vez más definido como el eje de toda la economía cubana, terminó en manos de la elite comercial, la cual, al disponer de mayores cuantías de capital pudo asumir làs exigencias derivadas del rápido desarrollo de las fuerzas productivas en el sector industrial. ${ }^{31}$

El poder español, mientras tanto, se veía forzado a recomponer de forma virtual la alianza con los criollos esclavistas y a seguir ponderando las iniciativas de la fracción reformista hasta donde no coincidieran con sus intereses esenciales. Captaba, primero, que era forzoso aceptar un plano de pacto negociado, a fin de prevenir la emergencia de actitudes abiertamente contrarias. Segundo, los gobernantes españoles comprendieron que los reformistas seguían siendo buenos compañeros de ruta, no obstante los recelos que les inspiraban ya que sus iniciativas propendían a un incremento de la riqueza pública. Y, para contener cualquier desbordamiento radical de los conflictos, el poder metropolitano

29 Sobre todos estos movimientos, cfr. Dirección Política de las FAR, op. cit., p. 86-102.

30 Sobre el entorno político de la decadencia de los hacendados esclavistas criollos, véase a Thomas, op. cit., p. 309-323.

31 Buenas síntesis sobre las contradicciones estructurales del esclavismo para mediados de siglo se encuentran en Julio Le Riverend, en Historia economica de Cuba, La Habana, 1970; y Francisco López Segrera, en Cuba: capitalismo dependiente y subdesarrollo, La Habana, 1972. 
potenció su intransigente defensa de las instituciones esclavistas; así, ante la espada de Damocles que representaba el $55 \%$ de personas de color existente en la primera mitad del siglo XIX (entre los cuales el $40 \%$ estaba compuesto por esclavos), la protección metropolitana era la única que legalmente podía imaginarse.

Este imperativo político explica que, a pesar de las relaciones básicamente de cooperación que se habían desarrollado durante décadas entre los reformistas y los capitanes generales, cuando advinieron para la clase esclavista las dificultades de reproducción arriba explicadas, se declarara un conflicto sin precedentes entre una parte de los reformistas y las autoridades. Algunos intelectuales criollos entendieron que ya había llegado el momento de introducir reformas que preparasen, a la larga, la abolición de la esclavitud, cosa que, evidentemente, no interesaba a las autoridades. El diferendo dio lugar al destierro del país de algunos de los intelectuales reformistas, como José Antonio Saco y Domingo del Monte. Como se verá más adelante, esos intelectuales se adelantaban a la lógica inmediatista de su clase, aferrada a los marcos juzgados inevitables de la esclavitud. En contraste, captaron que el sistema esclavista estaba irremediablemente condenado y que su prolongación no haría sino acelerar la ruina completa de la clase. A diferencia de la benevolencia con que se trató antes a los reformistas, ahora pasaron a ser objeto de la represión. Se puede explicar la recurrencia por el régimen de excepción, pero sobre todo por la variacion de las posturas reformistas. En efecto, mientras Arango proponía la generalización de la esclavitud, tendía a adecuarse con el poder español. Saco, por el contrario, al proponer la prohibición de la trata y la abolición posterior, chocaba con las conveniencias de España, que requería de la esclavitud en Cuba, tanto por las riquezas que le deparaba como por la compactación que generaba respecto a ella de parte de los hacendados.

Esta ruptura tuvo enormes consecuencias en el desarrollo de la cuestión nacional cubana, porque estimuló la aparición de una oposición política a la dominación española dentro de los sectores dominantes. Con la ruptura de los reformistas, aunque éstos como bloque no se orientaran hacia una posicion abiertamente antiespañola, se prepararon las condiciones para el surgimiento de orientaciones radicalizadas en el seno de la clase esclavista, sobre todo en tanto que sus posibilidades de reproducción estaban, a mediados de siglo, amenazadas por las contradicciones antes enunciadas.

Se fue generalizando, entonces, tras las sanciones a los intelectuales reformistas, una orientación política dominante dentro de los esclavistas. Se trataba del anexionismo a los Estados Unidos, indirectamente, aunque a menudo de forma directa, tal corriente estuvo alentada por las pretensiones de círculos de poder de los Estados Unidos de anexarse la isla. ${ }^{32}$ Para los esclavistas resultó ser casi una opción condicionada por el sentido común: casi toda la producción azucarera tenía por destino al vecino septentrional; de darse una integración política, se eliminarían las barreras arancelarias, lo cual se pensaba sería un resorte para incrementar la producción y eliminar las contradicciones que iba ya confrontando el orden esclavista. ${ }^{33}$ No hay que olvidar, por otra parte, que los

32 Un detenido estudio de las relaciones internacionales en torno a Cuba, durante el siglo XIX, lo ha realizado Ramiro Guerra, en En el camino de la independencia, La Habana, 1930.

33. Cfr. Thomas, op. cit., p. 289-307. 
estados del sur concentraban la mayor población esclava de América, de suerte que para los esclavistas cubanos los vecinos Estados Unidos eran un baluarte del orden social. Además, era la época de incubación del filibusterismo del norte que, mediante aventuras insensatas, pretendio la generalización de la esclavitud en la cuenca del Caribe.

La primera manifestación conocida de anexionismo se produjo en 1810 , cuando, en medio del debate en torno a la organización de la autoridad local ante el vacío de poder en la metropoli, los hacendados del cabildo de La Habana enviaron una propuesta confidencial de anexión a Washington. Aunque no fue aceptada, desde entonces se mantuvieron relaciones políticas entre ambas partes. Los esclavistas entonces comenzaban a captar la conveniencia de su integración al mercado del vecino norteño. Tales percepciones se acrecentaron en lo adelante por la presión que recibía Madrid del gobierno británico para abolir la trata de esclavos y, luego, la propia esclavitud. En ese contexto, la mayoría de los hacendados se alineo tras el principio de que, en caso de que el gobierno español pretendiese una variación en el statu quo social, o si se presentase la inminencia de la independencia, se orientarian abiertamente por la entrega a Estados Unidos. De forma que a partir de los años 20, bajo el temor de las presiones británicas y con la ampliación de las relaciones con el vecino norteño, el anexionismo pasó a constituir un reflejo político crucial. Los núcleos de dicha corriente se encontraban en distintas instituciones corporativas. En todo caso, el anexionismo resultó ser correlativo con el grado de dinamismo empresarial, pues se ajustaba a las fracciones más modernizantes de esclavistas.

Más adelante, desde los años 40 , sectores destacados de los plantadores decidieron impulsar con decisión la opción anexionista, la que dejaba de verse como una alternativa ante la emergencia de otras contrapuestas. Aun entonces el grueso de los activistas anexionistas al interior de la isla no superó la instancia conspirativa. El momento cumbre de esa corriente fue propiciado por las actividades del general Narciso Lopez, uno de los 25 mil emigrados que habían llegado a la isla de las otras colonias españolas de la zona, y quien se había distinguido combatiendo a los ejércitos de Bolívar. Tras haber montado una amplia conspiración, emigró a Estados Unidos y desde allí organizó varias expediciones filibusteras, cuyos integrantes eran fundamentalmente aventureros sudistas. Al fracasar la última, en 1850, Lopez fue capturado y fusilado, consciente de haber sido un instrumento de las mezquindades del sistema norteamericano.

López fracasó al no lograr concitar el apoyo activo, tras su emigración, de los esclavistas. En cierta medida, el alejamiento de una porción considerable de la clase dominante criolla se puede atribuir a los procedimientos beligerantes de López; los hacendados temían que el desencadenamiento de una guerra con España abriese las grietas para una rebelión de esclavos. Y, aunque seguían aspirando a la integración al vecino norteño, juzgaron más conveniente que ese paso se produjese de forma legal, justamente tal como lo concebían las principales autoridades de Washington. De ahí que en ciertos aspectos el líder anexionista esbozara elementos programáticos que superaban los encuadramientos clasistas. Concibio la creación de un estado antillano, compuesto por Cuba, Santo Domingo y Puerto Rico, sin que dejara claro cómo la compaginaba con el anexionismo. Los insurgentes posteriores de hecho recogieron su legado, viendo en el personaje no tanto al anexionista, sino a un precursor del nacionalismo cubano. La 
bandera diseñada por López, que cvocaba la creación de un nuevo estado de los Estados Unidos, fue ratificada como enseña nacional.

$\mathrm{El}$ anexionismo se insert6, como antes se dijo, en las tendencias expansionistas que se originaban en los círculos dirigentes de los Estados Unidos. Como es sabido, la política norteamericana osciló, en el siglo XIX, entre las disyuntivas de desarrollo intenso hacia adentro o expansión territorial. Como parte de la segunda línea se enunció la doctrina del "destino manifiesto". De tener una extensión de menos de un millón de kilómetros cuadrados a fines del siglo XVIII, la expansión del territorio hacia el oeste y el sur hizo de Estados Unidos una potencia continental de más de cuatro millones de kilometros cuadrados, aunque los territorios anexados estaban virtualmente despoblados. En cambio, a mediados del siglo XIX Cuba tenía cerca de un millón de habitantes y ocupaba una plaza señera dentro de las economías de exportación de productos tropicales. Uniendo a lo anterior el hecho de que gran parte de los géneros cubanos de exportación se dirigían a Estados Unidos, se explica que Cuba pasara a ser un objetivo crucial de la doctrina del "destino manifiesto". A lo largo del siglo XIX, cuando en Estados Unidos predominaban los sectores interesados en el expansionismo y las condiciones parecían propicias, se reiteraron los ofrecimientos de comprar la isla a la corona española. El primero que intentó la captura de Cuba por ese medio fue el presidente Thomas Jefferson; a partir de sus observaciones se hizo doctrina oficial de Washington, durante las décadas ulteriores, el criterio de que la anexión de Cuba no debía llevarse a cabo por medio de la violencia o de guerra declarada, sino que debía responder a lo que se denomino "fruta madura"; esto es, la adquisición de Cuba debía resultar de un proceso armónico, surgido de la imposibilidad ulterior de España para sostener su dominación.

De tal manera, el predominio del anexionismo entre los hacendados esclavistas se retroalimentó poderosamente con el pronunciado interés que se manifestó en Estados Unidos. Por otra parte, la agudización de las tensiones entre los estados del norte y del sur de Norteamerica durante las dos décadas previas a la guerra de secesión, introdujo matices al interés por la isla: en particular, muchos políticos sudistas consideraron que la incorporación de Cuba, dadas su población y riquezas, inclinaría la balanza a su favor. Por eso, la generalidad de los grupos de emigrados cubanos que se organizaron en los Estados Unidos, contaba con la simpatía declarada de políticos sudistas. Quizás por esta razón, y con el predominio norteño, en los círculos de Washington fue perdiendo importancia la idea de una anexión a corto plazo de la isla. Por lo demás, como es sabido, tras la guerra civil terminaron por prevalecer las posiciones tendentes a sustentar el avance nacional en los recursos del territorio ya existente.

\section{La avanzada de los intelectuales criollos}

Mientras la clase esclavista se orientaba hacia el anexionismo, de su interior emanaban expresiones que respondían a una intelección de sus intereses en el largo plazo. El hacendado normal pensaba en términos de la ganancia inmediata y, por eso, no esbozó ninguna alternativa al régimen de la esclavitud y del sometimiento colonial. Contrariamente, algunos intelectuales criollos llegaron a la comprensión de los grandes dilemas que se le presentaban a la clase a la que pertenecían. Al hacer- 
1o, dichos intelectuales se marginaron de la clase y, en aras de sus intereses globales, entraron en conflicto con sus intereses inmediatos.

Dos figuras sobresalieron a ese respecto. Fueron los ilustres intelectuales, ya mencionados, presbítero Félix Varela y José Antonio Saco. El primero tuvo que huir de España, tras la entrada de los 10000 hijos de San Luis, al apoyar una moción en las Cortes contra Fernando VII. En Estados Unidos amplió sus propuestas políticas, desde el autonomismo al independentismo. En cuanto a la esclavitud, Varela llego a la conclusión de que era imprescindible su abolición, fundamentando esto en el peligro de revolución que representaba la gran masa subyugada; Saco, por su parte, fue deportado de la isla al exigir derechos políticos. En Europa no transitó hacia el independentismo, pcro amplió su combate al tráfico negrero, y se formuló los medios para que se fueran creando condiciones para la abolición de la esclavitud sin que ello afectara los intereses de los hacendados. ${ }^{34}$

En ambos intelectuales se presentaba, pues, la relación entre una apertura de la comunidad nacional en vinculación con la autonomía o la independencia y la abolición de la esclavitud. Aunque Saco no llegó a plantearse la independencia, esbozó nociones muy claras del fenómeno nacional, viendo en la dominación española algo transitorio. Por su percepción avanzada se opuso a la corriente anexionista, no obstante las estrechas relaciones amistosas que lo unían con sus adalides clandestinos. Previó, incluso, el peligro de absorción de parte de los anglosajones que se presentaría a la nación cubana ${ }^{35}$ Saco era consciente de la formación de una comunidad de destino entre los cubanos, pero juzgaba necesario no acelerar procesos en razón de los intereses de su clase, los que relacionaba con la idea de civilización. En todo caso, ambos pensadores asociaron la creación de condiciones óptimas de régimen político y social sobre la base de la igualdad jurídica de corte burgués, medio de garantizar la prolongación del dominio de clase en el marco de la autonomía o la independencia.

En esta relación no dejaron nunca de mantener las líneas de exclusión de lo popular, aunque en algunos aspectos Varela esbozó criterios distintos. Los esclavos, por ello, estaban excluidos de su representación en lo nacional. En gran medida, todo lo que proponían estuvo en función de prevenir el alzamiento revolucionario de los esclavos. Más incisivo a este respecto, Saco basó su rechazo al anexionismo con el argumento de que lograría la escisión de los blancos y de ello la aparición en escena de los esclavos. Para conjurar ese peligro vital, propuso en numerosas ocasiones la intensificación de la corriente migratoria de españoles a la isla.

Como secuela de la radicalización de parte de los intelectuales, un precedente indirecto de la primera guerra de independència fue la recuperación de la corriente reformista. Advino lo que los historiadores han denominado tercera fase del reformismo, con la fundación, en 1865, de una suerte de movimiento político. Su proclama constitutiva obtuvo la adhesión de más de 20 mil personas. Se produjo un claro giro hacia el

34 Una selección de textos de Varela, en Hortensia Pichardo, op, cit., p. 267-288. Saco tuvo una extensa producción intelectual. Entre otras cosas es importante su Colección de papeles cientificos, historicos, politicos y de otros ramos sobre la Isla de Cuba. (2 tomos), La Habana, 1962.

35 Cfr. José Antonio Saco, "Ideas sobre la incorporación de Cuba en los Estados Unidos", en Hortensia Pichardo, op. cit, p. 333-349. 
autonomismo y a la demanda de la abolición de la esclavitud. Aunque siguiese constituyendo una alternativa francamente opuesta a la de la independencia, la emergencia del movimiento no dejaba de evidenciar la preparación de una crisis global de la dominación española.

Lo anterior explica que los avances de esos intelectuales sólo tuvieron consecuencias finales ulteriores, cuando se escindio el campo de los hacendados con la aparición de un sector autonomista y otro favorable a la independencia. Ello resultó de la agudización de las contradicciones de la economía de plantación esclavista y del fracaso de las tentativas anexionistas. Pero, aunque tardíos, los proyectos de los intelectuales en cuestión fueron de gran relevancia en la preparación de las condiciones para la apertura de la lucha armada contra la dominación española.

\section{La preparación de condiciones para la lucha por la independencia}

El devenir de los acontecimientos en los Estados Unidos contribuyo, en parte, a que el anexionismo comenzara a agotarse a la vuelta del medio siglo y quedara completamente liquidado con la guerra de secesion. El cambio de manos del sector azucarero introdujo otros componentes a los reflejos de los hacendados, puesto que, al quedar el grueso de la producción azucarera en manos primordialmente de peninsulares, las contradicciones con la metrópoli asumieron otros lineamientos. Se produjo una diferenciación de intereses al interior de la clase dominante criolla detentadora de los medios de producción. La parte que subsistía finalmente buscaba los espacios de negociación con la metrópoli. Esta tendencia se fortalecía con la incorporación masiva de peninsulares al ámbito productivo y con el incremento de beneficios para quienes subsistían.

En 1860, a pesar de las dificultades que encontraba la trata, se contaron 371 mil esclavos, lo que evidenciaba el enorme poder que mantenía la clase dominante; y aunque este número había significado una disminución respecto al máximo de 430 mil en 1841 , los excedentes se potenciaban por la incorporación generalizada de adelantos tecnológicos cada vez más sofisticados, como el tacho Derosne o la centrífuga. Hay que anotar que, a partir de esa fecha, se registró un intenso proceso de centralización del capital: el número de plantaciones disminuyó desde 2000 en 1860; a 1190 en 1878; y a 207 en 1898. La mitad de la zafra se llevaba a cabo en un reducido territorio; así, en el llamado triángulo Matanzas-Cárdenas-Colón, un 5\% de los ingenios producía más del $25 \%$ de la zafra.

En contraste con la posición privilegiada de una minoría de esclavistas, el grueso de la clase iba a la quiebra o quedaba en posición muy marginal. Se desató, entonces, una lucha entre las fracciones de esclavistas por su posición en los procesos ya vistos. En particular, vale destacar el mantenimiento de un sector marginado en el oriente, donde existía todavía el hato ganadero primitivo, el ingenio pequeño y otras unidades agrícolas como los cafetales. ${ }^{36}$ La agonía de los pequeños esclavistas y

36 La actividad cafetalera había tenido una gran importancia en la economía cubana hasta la década de los 40 . En la década de los años 30 se contaba con un número similar de esclavos dedicados al azúcar y al café (unos $50 \mathrm{mil}$ en cada renglon), e incluso un fondo territorial superior en los cafetales. La actividad decayo por una convergencia de 
la quiebra de una gran parte de los mismos, muy traumática en ciertas actividades como el café, determinó el giro de una parte destacada del sector a posiciones anti-españolas que ya no desembocaba necesariamente en el anexionismo y avanzaban hacia el independentismo.

Ese giro de gran parte de la clase dominante de la banda oriental entrañaba un conflicto de naturaleza distinta que el ya señalado. Se trataba de que, desde fines del siglo XVIII, la formación de la economía esclavista se había llevado a cabo primordialmente en la zona occidental, sobre todo entre La Habana y el occidente de Las Villas. Se manifestaba, ante todo, en la concentración de la producción azucarera, que tenía por efecto profundizar el atraso en el resto del país, implicando una subordinación del oriente por el occidente y el flujo de excedentes desde una zona hacia la otra. ${ }^{37}$ Esta explotación se basaba en redes comerciales que establecían precios desventajosos para el oriente; en especial, el aprovisionamiento del ganado destinado a alimentar a los esclavos de las plantaciones del occidente se llevaba a cabo a precios muy desventajosos para los hacendados orientales, con lo que éstos resultaban subsidiando al esclavismo evolucionado.

La contradicción de los hacendados orientales se inscribió dentro de un conflicto social más vasto, que abarcaba la inconformidad de la generalidad de la población de la banda oriental con el sistema socioeconomico existente y, por ende, con la forma política que lo sustentaba: la dominación española. Esto determinó que el oriente fuese la cuna de la confrontación de masas contra España y que, por ello, la primera guerra de independencia, denominada de los Diez Años por haberse llevado a cabo entre 1868 y 1878, se desarrollara exclusivamente en la banda oriental. ${ }^{38}$ Durante esta contienda el ejército español abrió una trocha, en el occidente de Camagüey, que atravesaba la isla de costa a costa en un punto estrecho. Las huestes independentistas nunca pudieron traspasarla, lo cual no se debio a un factor militar, sino a que en la banda occidental, al otro lado de la trocha, no se habían creado las premisas políticas y culturales para el estallido de una sublevación de masas por la independencia.

En relación a lo último se deben señalar las diferencias que la diversidad de sistemas económico-sociales habían creado entre oriente y occidente. En occidente se concentraba la gran mayoría de la población esclava, ${ }^{39}$ la cual, por su situación, no podía generar una identificación

circunstancias, como la cerrazón del mercado norteamericano a consecuencia de una guerra de tarifas entre los EE. UU. y España en 1834, una sucesión de ciclones, y, sobre todo, por la tendencia creciente a que la tasa de beneficios se hiciese mayor en el azúcar, lo que generó trasiegos en los capitales (sobre todo en los esclavos) y la ocupación de las tierras. Cfr. Juan Pérez de la Riva, El barracón y otros ensayos, La Habana, 1965.

37 Aunque influenciado por la teoría del colonialismo interno de Gunder Frank, el fenómeno ha sido tratado por Lopez Segrera, op. cit, passim, en una perspectiva que nos parece básicamente correcta.

38 Sobre este episodio, véase a Ramiro Guerra, Guerra de los Diez Años, La Habana, 1970. 39 El siguiente cuadro muestra cómo más del $80 \%$ de los esclavos se localizaban en la parte occidental de la isla. Aunque se refiere a 1869 , es indicativo de una situación proveniente de muchas décadas antes.

Población de Cuba según grupos de color, 1869 (en miles)

$\begin{array}{lccccc} & \text { Blancos } & \begin{array}{c}\text { Libres de } \\ \text { color }\end{array} & \text { Esclavos } & \begin{array}{c}\text { Total } \\ \text { de color }\end{array} & \begin{array}{c}\text { Total } \\ \text { general }\end{array} \\ \text { Occidente } & 601 & 142 & 301 & 442 & 1077 \\ \text { Centro } & 49 & 14 & 15 & 29 & 78 \\ \text { Oriente } & 119 & 83 & 47 & 131 & 245 \\ \text { Total } & 763 & 239 & 363 & 601 & 1400\end{array}$


nacional. En esa zona, por otra parte, se aglomeraba la poblacion de peninsulares, en general bastante significativa, superior al $20 \%$ en las ciudades y zonas económicas dinámicas. ${ }^{40}$ Este sector tampoco podía identificarse a un sentimiento naciónal, puesto que veía a la isla como una simple prolongación de la península y consideraba que su status era superior al de los nativos, y debía garantizarse por medio de la prolongación indefinida de la soberanía española.

En el oriente, el panorama social y demografico era muy distinto: poca población esclava, pocos peninsulares y mayoría de población mulata. Por otra parte, no predominaban las relaciones esclavistas, y en las existentes sobresalían las no evolucionadas, teniendo mucho peso la hacienda primitiva y la pequeña agricultura independiente de autosubsistencia. Este perfil social y demográfico acentuaba el hecho nacional así como su intelección, de donde resultó una exacerbación del conflicto con la metrópoli. De tal manera, el factor de los grupos dominantes tiene importancia en la raíz de la oposición oriental, pero sólo de manera parcial. Conjunta y destacadamente, incidía un hecho popular, imbricado a los fenómenos esenciales de eclosión de la nación cubana. En efecto, los prototipos del libre de color y del blanco pobre se asociaban nodalmente a la creación de un conglomerado particular, diferente del español, dotado de capacidad de autopercepción.

Sería esta dualidad de orígenes sociales la que conferiría sus características contradictorias a la Guerra de los Diez Años. ${ }^{41}$ Diversos fenómenos históricos despejaron la formación de un sujeto nacional-popular. El más decisivo fue, sin dudas, la decadencia del orden esclavista. Como se ha visto, se encontraba en una situación de por sí difícil para inicios de los años 60 . En ello incidió la presión subrepticia que mantenía la masa esclava, junto a otros fenómenos como la beligerancia británica.

En todo caso, a partir de la consideración del peligro que representaba la gran masa esclava, las autoridades juzgaron necesario inclinarse ante las advertencias de José Antonio Saco. Influyó mucho en ese sentido la oleada de sublevaciones que se propagaron en 1843, al parecer vinculadas a la más extensa de las conjuras de los esclavos. Para cortar de raíz el peligro, las autoridades acudieron, durante el año siguiente, a una represión sin precedentes, utilizando un método de tortura conocido como "la escalera". De ese calificativo provino el nombre de la conjura. Miles de esclavos y libertos fueron detenidos y varios cientos entre ellos ejecutados, casi siempre tras atroces torturas. La represión fue tan dura que logro el efecto deseado de aplacar la acechanza de los esclavos. En lo adelante, el trato hacia ellos fue por primera vez reglamentado, y se tomaron medidas para evitar que siguiesen creciendo en forma desmesurada respecto a la población blanca.

En términòs estructurales y políticos se conjuro, para mediados de siglo, la alternativa de una insurrección general de esclavos. Tal hecho tu-

$400^{\circ}$ Para 1860, la relación entre cubanos y españoles en las gobernaciones de occidente y oriente era la siguiente:

$\begin{array}{lcc} & \text { Cubanos } & \text { Españoles } \\ \text { Occidente } & 385 & 73 \\ \text { Oriente } & 128 & 10 \\ \text { Total } & 513 & 83\end{array}$

- $\quad$ FUENTE: Hortensia Pichardo, op. cit., p. 365

41 Véase sobre este punto a Fernando Portuondo, Estudios de historia de Cuba, La Habana, 1973. 
vo consecuencias en cuanto a la reorientación independentista de ciertos núcleos criollos, y sobre todo de la generalidad de la población blanca no dominante. La disminución de la proporción de esclavos, ${ }^{42}$ por otra parte, contribuyo a fortalecer el sector de libertos y libres de color, entre los cuales surgían con cada vez mayor nitidez autopercepciones de corte nacional.

La cristalización final de la conciencia nacional fue resultado del traslado de los conflictos con el poder metropolitano desde el ámbito estructural o subrepticio al de la lucha social abierta, básicamente por medio insurreccional. De esa manera, las dos guerras de independencia constituyeron verdaderos crisoles de solidificación del colectivo nacional. La lucha social despejo los obstáculos que seguían interfiriendo la final integración de la comunidad de destino. Por eso, se dará una relación estrecha entre ampliación de la lucha y la radicalización de sus objetivos. Inicialmente, los rebeldes de Oriente no abolieron la esclavitud, al pretender ganar a su causa a parte de los plantadores occidentales. Al poco tiempo, tal visualización fue descartada. Los sectores hacendados, que siguieron teniendo mucha presencia, sobre todo en Camagüey, tuvieron que adaptarse a la parcial radicalización del campo independentista. Hay que tomar en cuenta que los sectores dominantes criollos tradicionales habían entrado en una pendiente de disgregación, lo cual constituiría un factor de mucha relevancia no sólo en las luchas por la independencia sino en el proceso histórico posterior que culminó con la revolución de Sierra Maestra. Aunque presentes, los hacendados no pudieron proyectar con fuerza mecanismos de hegemonía. Resultado de esa debilidad, se esfumó por completo el anexionismo, el que no había dejado de asomar en los tiempos iniciales de la Guerra de los Diez Años.

En cambio, los sectores populares ganaron terreno. Si bien en la Guerra de los Diez Años los sectores dominantes todavía lograron mantener cierta hegemonía práctica en el bando insurgente, ello no descartó una tendencia a la radicalización. La misma determinó que la segunda guerra de independencia asumiese un perfil social distinto, al darse la interacción entre una base de apoyo plenamente popular ${ }^{43}$ y un liderazgo que tendió a expresar la eclosión del sujeto nacional del pueblo cubano. Todo ello se manifestó en el liderazgo de figuras de extraordinaria consistencia y perfil netamente progresivo, como Máximo Gómez y Antonio Maceo, que fueron las que condujeron la acción militar en las dos guerras. El genio excelso de José Martí, a su vez, sintetizó el avance doloroso de la conciencia nacional del pueblo.

Por la radicalización social de objetivos y sus sistematizaciones en el liderazgo intelectual y militar, el proceso de luchas por la independencia en Cuba adquirio un contenido totalmente distinto al que tuviera en el continente a inicios de siglo. ${ }^{44} \mathrm{La}$ tardanza del proceso en el contexto de la introducción del capitalismo y la acechanza de Estados Unidos determinaron que en Cuba no se diese una clara solución de continuidad entre la lucha por la independencia y procesos ulteriores que desembocaron, desde los años 30 , en una suerte de crisis permanente de hegemonía.

42 Sobreel proceso de decadencia y abolición de la esclavitud, véase Rebeca J. Scott, "Gradual Abolition and the Dynamics of Slave Emancipation in Cuba, 1868-86", en Hispanic American Historical Review, vol. 63, núm. 3, agosto de 1983, p. 449.447.

43 En la segunda guerra, de acuerdo a varios testimonios, cerca del $80 \%$ de los combatientes mambises eran negros. Thomas, op. cit., p. 423, concluye correctamente: "Esta era, por lo tanto, una guerra revolucionaria, no simplemente de independencia."

44. La idea ha sido desarrollada por Ricaurte Soler, Idea y cuestion nacional latinoamericanas, México, 1980. 